\title{
EXPLORING LOCAL WISDOM FROM YOUTUBE: AN INVESTIGATION ON THE INDONESIAN HIGHER EDUCATION STUDENTS' DANCE PERFORMANCE ACROSS GENDER
}

\author{
Fuji Astuti \\ Universitas Negeri Padang, Indonesia \\ e-mail: astuti@ffbs.unp.ac.id
}

\begin{abstract}
Technology-based media can increase students' motivation more than equipping their teaching materials with traditional ones. This article aims to describe the difference between the dance performance of students taught by exploring local wisdom from YouTube and those who are taught by the conventional method. This quasi-experimental study describes whether local wisdom and technology via YouTube can effectively increase Indonesian students' dance performance at the higher education level. A number of 205 students participated in this research. A dance performance test, two scoring rubrics, and a questionnaire were used. The result of statistical analysis shows that exploring the values of local wisdom from YouTube videos can give a significant effect on students' dance performance with sig. $=.000$. In terms of gender, there is a significant difference between female and male students after being taught by exploring local wisdom from YouTube videos (sig. $=.000$ ). Moreover, females also achieve better than males in terms of creativity including fluency, flexibility, elaboration, and originality of their dance products. The results of the questionnaire reveal that students appreciate and feel helped by integrating local wisdom and YouTube videos in the choreography course and agree that the values of local wisdom direct their dance performance in terms of movement, attitude, costume, and creativity.
\end{abstract}

Keywords: local wisdom, YouTube videos, dance performance, creativity, gender.

\section{MENGGALI KEARIFAN LOKAL MELALUI YOUTUBE: SEBUAH STUDI PERTUNJUKAN TARI MAHASISWA INDONESIA LINTAS GENDER}

\begin{abstract}
Abstrak: Media berbasis teknologi dapat meningkatkan motivasi mahasiswa lebih baik daripada bahan ajar tradisional yang diajarkan. Artikel ini bertujuan untuk menggambarkan perbedaan antara pertunjukan tari mahasiswa yang diajar dengan menggali kearifan lokal pada video YouTube dan metode konvensional. Penelitian eksperimen semu ini mengkaji apakah kearifan lokal dan teknologi YouTube dapat secara efektif meningkatkan hasil tari mahasiswa Indonesia di jenjang perguruan tinggi. Sebanyak 205 siswa berpartisipasi dalam penelitian ini. Tes penampilan tari, dua rubrik penilaian, dan angket digunakan untuk mengumpulkan data. Hasil analisis statistik menunjukkan bahwa nilai-nilai kearifan lokal dari video YouTube dapat memberikan pengaruh yang signifikan terhadap penampilan tari siswa $($ sig. $=0,000)$. Ditinjau dari jenis kelamin, terdapat perbedaan yang signifikan antara siswa perempuan dan laki-laki setelah menggali kearifan lokal melalui video YouTube $($ sig. $=0,000)$. Selain itu, mahasiswa perempuan juga berprestasi lebih baik daripada laki-laki dalam hal kreativitas, seperti kefasihan, fleksibilitas, elaborasi, dan orisinalitas produk tari mereka. Hasil angket menunjukkan bahwa siswa mengapresiasi dan merasa terbantu dengan pengintegrasian kearifan lokal dan video YouTube dalam mata kuliah koreografi serta sepakat bahwa nilai-nilai kearifan lokal mengontrol penampilan tarian mereka dari segi gerak, sikap, kostum, dan kreativitas.
\end{abstract}

Kata Kunci: kearifan lokal, video YouTube, pertunjukan tari, kreativitas, gender.

\section{INTRODUCTION}

The integration of technology in the learning process encourages educators to engage more in several technology-based media. The technology-based media can increase students' motivation instead of equipping their teaching materials with traditional ones, such as textbooks, job-sheet, etc. In the context of higher education, the technology advancement also persuades lecturers to use several media, such as YouTube 
to encourage students to be more active, and make the situation more contextual (Gratsiouni $\&$ Koutsouba, 2016). The popularity of YouTube in this millennial era gives chances to lecturers to take the benefits and integrate it as the media of learning in class. In addition, the combination of YouTube and discussion activities can create positive effects on the students' learning outcomes (Fleck, Beckman, Sterns, \& Hussey, 2014).

A previous research study has examined the effectiveness of YouTube videos on students' learning outcomes (Olasina, 2017). Some of them also have evaluated students' attitude toward the integration of YouTube in the learning process (Buzzetto-More, 2015), explored the potential videos from YouTube for teaching (DeWitt, Alias, Siraj, Yaakub, Ayob, \& Ishak, 2013), and investigated the students' perception of using YouTube in classrooms (Fleck et al., 2014). All of them agreed that integrating Youtube in learning is useful, and it perceives helpfulness on students' engagement in class. Jackman (2019) also suggests the lecturers to integrate YouTube in the process of learning because it gives some benefits; for example, it provides audio-visual concept which makes students receive the information from the two modes, listening and viewing, encourages students' collaborative and networking skills, and provides real-life condition leading to contextual learning.

In the context of teaching dance, there is little research evidence concerning the application of YouTube to enhance college students' dance performance. Gratsiouni \& Koutsouba (2016) who have done the research focusing on the activity of Greek traditional dance found that students can be more active in participating in the learning process using YouTube. Olasina (2017) claimed that YouTube can be fitted to the pedagogy, and it can be used as a fundamental platform to develop technopedagogy in classrooms. However, the missing point in their research was on excavating the values of local wisdom of the dance videos that are watched by the students. Local wisdom as a part of a culture, which is derived from the deal of a certain community, controls people's acts in daily life. The local wisdom can maintain local values through dance performance, especially in local or traditional dances (Anttila, Martin, \& Nielsen, 2019; Edwards, 2018). Thus, it can be more meaningful if the use of technology, such as YouTube can be as a medium to excavate local wisdom. And, the local wisdom derived from criticizing several dance videos on YouTube can be as considerations for students to create their local or traditional dances.

Choreography dance aims to increase students' creativity in organizing and developing local or traditional dances (Triana, 2015). The course also aims to develop students' creativity and capability in producing local or traditional dance. It is in line with Humphreys \& Kimbrell (2013) who claim that the curriculum on choreography dances either in private or public education should develop students with capability in creating meaningful dances. It means that the lecturers should encourage the students to develop their skills, explore what they get from several sources, and expand the dance that can be potentially choreographed (van Dyke, 2005). However, in the context of choreography dance focusing on traditional or local dances, the lecturers cannot ignore the roles of local wisdom. The local or traditional dances should represent the local wisdom of the area in which the dances are firstly produced by the community (Indrayuda, 2016). And, to date, there is no research concerning the process of creating local dances following the values of local wisdom. Riyaningsih, Maryono, \& Harini (2018) have claimed that the traditional dances in which the local wisdom is reflected give benefits to increase students' creativity and establish their characters, such as cooperative, honesty, responsible, and tolerance. As stated by Priyanto (2005), students can visit an object to explore the information contributing to their dance creativity. Thus, further research studies need to focus more on examining the effect of excavating local wisdom from YouTube videos on students' dance performance.

Moreover, as previously stated by Triana (2015), choreography dances cannot be separated from the students' creativity. Milyartini \& Haerani (2013) also claimed that creativity is one of the characteristics that students have to have. It refers to the ability to create things which are useful and meaningful (Wicaksono, 2009). Although many researchers have investigated elements in dance choreography such as examining the formative and summative assessment in choreography dance (Milling \& 
Green, 2014), the correlation between variables within the choreography dance (Musil, 2005), investigating the design and approach in teaching choreography dance (Lepczyk, Wagner, \& Cennamo, 2018; McClam, 2018; Ohlberg, 2020), examining the proposed treatments in choreography dance (Butterworth, 2004; MacBean, 2004; van Dyke, 2005), exploring the ethics and values in choreography dance (Calamoneri, Dunagan, \& McCarthy-Brown, 2020; Urmston \& Aujla, 2019), investigating professionalism in teaching choreography dance (Wilmot, 2019), exploring communal in dancing (Chang \& Hogans, 2019), and creative process in choreography (Alaways, 2020; Clements \& Redding, 2020), references to the impact of students' local wisdom on students' creativity are still few. It can give more comprehensive results if the comparison between creativity in dance performance after local wisdom has been implemented is also examined.

It is important to know the impact of students' creativity after excavating the local wisdom from YouTube videos. Creativity is a part of wisdom produced by the human brain (Wu, Wu, Chen, \& Chen, 2014) and students in the choreography course have to be encouraged to develop dance through their creative process (Riyaningsih et al., 2018). It means that there might be a link between local wisdom and students' creativity. Besides, little research evidence in investigating students' creativity in producing dances across gender. A research study reported that females have higher creativity than males. (Matud, Rodriguez, \& Grande, 2007). Besides, some of them also found that females have higher motivation and positive psychological, sensitivity, self-strength, intellectuality, and individuality than males (Amado, Sanchez-Miguel, \& Molero, 2017; Naderi, Abdullah, Aizan, Sharir, \& Kumar, 2010). Indrayuda (2016) has also indicated that the values of local wisdom may control every expression of female dancers more than males. One can give a new insight if we also examine the creativity of dancers in terms of fluency, elaboration, quality, and originality.

To sum up, there are some issues which are needed to investigate, such as the roles of local wisdom in teaching dance, YouTube, and students' creativity. Olasina (2017) found that videos on YouTube can improve students' performance by equipping some elements. Therefore, concerning the application of YouTube in the university context, specifically in teaching choreography dance, this article aims to describe the difference in students' dance performance taught by the excavating local wisdom from YouTube and those who are taught by the conventional method; to describe the difference in terms of creativity between males and females after being taught by the excavating local wisdom from YouTube; and to investigate students' perceived helpfulness of excavating local wisdom from YouTube in producing dances

\section{METHODS}

This quasi-experimental research was conducted in Arts, Drama, Dance, and Music Department at a public university in West Sumatera, Indonesia. The population was students who were taking the choreography course. The reasons for taking them as the samples are 1) they have passed previous courses, namely concept of composing dance in semester 3 and composing dance in semester 4,2 ) they have adequate knowledge in constructing and producing movement, and 3) they have enough background knowledge on West Sumatera Local Wisdom. The cluster random sampling was used and the two groups, experimental (102 students) and control (103 students) were involved. The experimental group consists of 51 males and 51 females, meanwhile, the control group consists of 51 males and 52 females.

This research involved independent, moderator, and dependent variables. The independent variable was the excavating local wisdom from YouTube videos. The moderator variable was gender. The students' creativity and performance were the independent variables. The local wisdom that was explored on YouTube videos was the local wisdom in West Sumatera, Indonesia, namely Sumbang Duo Baleh (the twelve taboos). In this research, sixteen meetings including the administration of pre- post-test and the questionnaires were done. In the experimental group, the lecturer gave some lessons related to the theory of Sumbang Duo Baleh (the twelve taboos) to increase their comprehension of the values of the local wisdom. Then, the students were shown several traditional videos on YouTube and asked to identify what is wrong or taboo based on their 
comprehension. They are also asked to look for the other videos on YouTube and try to criticize the quality of dance performance and make reports about what they have evaluated. Based on their reports, they are asked to re-model the dance that they have watched by considering the originality, quality, and form. On the other hand, in the control group, the lecturer taught them by using YouTube only. The students in the control group only focus on imitating or copying the movements without concerning the values of local wisdom in every video they had watched. They were only equipped with the knowledge that they have learned from previous courses related to the quality, originality, and form of dance. It means that they have enough provisions related to how they create and consider their moves.

Four instruments were used, namely dance performance test, scoring rubric to assess students' dance performance, scoring rubric to assess students' creativity and questionnaire. The two scoring rubrics were adapted from Triana (2015). The validity of the test instrument was measured before the pre-test was held. The score of the validity given by the validators $(89 \%)$ indicated that the test was valid to be used. The reliability of the test was also measured using Cronbach's alpha, and it was claimed as a reliable test to be used. Besides, the validity and reliability of the rubric were also measured by the validators and the researcher. It was found that the rubric of dance performance $(90 \%)$ and students' creativity (88\%) are in high validity. To see the reliability of the scoring rubrics, other lecturers were asked to use the rubrics in their class. The results of the alpha coefficient of the dance performance rubric (.88) and students' creativity rubric (.82) were indicated that the rubrics were claimed as the highly reliable scoring rubrics.

To see students' perceptions, the questionnaire was made. The questionnaire was adapted from Astuti (2019) covering movement, attitude, costume, and creativity. The aspect of movement includes how they move their leg, head, and hand. The attitude includes how they ask, share, discuss, and collaborate in teams during creating dance. The costume aspect includes how they choose and wear the appropriate costumes for their dance performance. The creativity aspect includes the whole process of originality and uniqueness in determining movements, themes, and costumes. The questionnaire was tried out and analyzed. The reliability of the entire questionnaire was .842 as determined by Cronbach's alpha result. The data analyzed by descriptive and inferential statistic, i.e $t$-test.

\section{FINDINGS AND DISCUSSION \\ Findings \\ Comparison of the Post-Test Scores of the Students from the Experimental and Control Groups in Terms of Dance Performance}

The mean scores of students' dance performance between the two groups were compared using descriptive statistics, shown in Table 1. Then, the statistical analysis was employed to achieve a significant difference between students who are taught by local wisdom and those who are taught by the conventional method. To see the significant difference between both groups, the independent sample $t$-test was employed. The result was displayed in Table 2 .

Table 1. Descriptive Statistics of the Post-Test Scores between the Two Groups

\begin{tabular}{lcccc}
\hline Method & $\boldsymbol{N}$ & Mean & $\boldsymbol{S D}$ & Std. Error Mean \\
\hline Local wisdom & 102 & 84.02 & 4.947 & .490 \\
Conventional & 103 & 79.30 & 2.266 & .223 \\
\hline
\end{tabular}

Table 2. Comparison of the Post-Test Scores between the Two Groups

\begin{tabular}{|c|c|c|c|c|c|c|c|c|c|}
\hline & \multicolumn{2}{|c|}{$\begin{array}{c}\text { Levene's Test } \\
\text { for Equality of } \\
\text { Variances } \\
\end{array}$} & \multicolumn{7}{|c|}{$t$-test for Equality of Means } \\
\hline & \multirow[t]{2}{*}{$\boldsymbol{F}$} & \multirow[t]{2}{*}{ Sig. } & \multirow[t]{2}{*}{$t$} & \multirow[t]{2}{*}{$d f$} & \multirow{2}{*}{$\underset{\text { (2-tailed) }}{\text { Sig. }}$} & \multirow{2}{*}{$\begin{array}{c}\text { Mean } \\
\text { Difference }\end{array}$} & \multirow[t]{2}{*}{$S D$} & \multicolumn{2}{|c|}{$\begin{array}{l}\text { 95\% Confidence Interval } \\
\text { of the Difference }\end{array}$} \\
\hline & & & & & & & & Lower & Upper \\
\hline $\begin{array}{l}\text { Equal variances } \\
\text { assumed }\end{array}$ & .554 & .457 & 13.561 & 203 & .000 & 9.107 & .672 & 7.783 & 10.431 \\
\hline $\begin{array}{l}\text { Equal variances } \\
\text { not assumed }\end{array}$ & & & 13.557 & 202.056 & .000 & 9.107 & .672 & 7.782 & 10.432 \\
\hline
\end{tabular}


Based on the statistical data ( $p$-value $=$ .000 ), it was indicated that there was a significant difference between students who were taught by local wisdom in the choreography course than those who were taught by the conventional method. As shown in Table 1 , the mean score of students in the local wisdom class (84.02) was higher than the control group (79.30). It can be noticed that students who are taught by excavating local wisdom from YouTube videos achieve better dance performance than those who were taught by using the conventional method.

Besides, the descriptive and paired sample test was also used to compare male and female dance performance after giving treatment of excavating local wisdom. It can be seen from Table 3. The result of statistical analysis $(t(50)$ $=-19.365$, sig. value $=.000)$ was indicated that there was a significant difference in dance performance after being taught by integrating local wisdom in choreography dance across gender. Specifically, in Table 3, the mean score of females (87.84) was higher than males' (80.20). It indicates that female students show better performance than males in choreography dance after being taught by excavating local wisdom through videos on YouTube.

\section{Comparison of Dance Creativity between Male and Female Students after being taught by Excavating Local Wisdom through Videos on YouTube}

The mean score of students' between male and female in terms of creativity were compared using descriptive statistic. Then, the statistical analysis was employed to see the significant difference between the two groups. The paired sample test was also used to answer the research question number 2 which aims to see the comparison between males' and females' creativity. The statistical analysis, $(t(50)=$
-3.459 , sig. value $=.001$ ), showed that there was a significant difference between males' and females' creativity. Moreover, based on Table 3, the mean score of males (86.24) was lower than the mean score of females (89.22). It also can be inferred that the females' creativity achieves better than males after being taught by excavating local wisdom through videos on YouTube.

\section{Perceived Helpfulness of Local Wisdom in Dance Performance}

At this point, the students' perceptions toward the excavating local wisdom through videos on YouTube in the choreography course were revealed. They were asked to choose one of five options varying from strongly agree to strongly disagree. The result is shown in Table 4.

It was found that the scores of all students' responses concerning local wisdom in dance movement are above 4 value. It means that the excavating of local wisdom through YouTube videos perceived helpfulness to the higher students, especially in the choreography course. In terms of sitting and standing movements (Item \#1 and \#2), students strongly agreed that the local wisdom gives them various appropriate choices of movements. By accessing videos on YouTube, they can see several movements and consider the best movements which are appropriate and in line with the local wisdom values.

Moreover, in the aspect of attitude, all of them have a very good perception of the integration of local wisdom in terms of collaboration in the dance team (item \#10). They strongly agreed that sumbang bagaua (Taboos in getting along) helps them in terms of teamwork and collaboration with friends. They are free to access videos on YouTube, but they should be corporate with teams to choose which videos are suitable to evaluate and criticize.

Table 3. The Performance and Creativity Scores

\begin{tabular}{lcccc}
\hline & Mean & $\boldsymbol{N}$ & Std. Deviation & Std. Error Mean \\
\hline Performance Score & & & & \\
$\quad$ Male & 80.20 & 51 & 1.844 & .258 \\
$\quad$ Female & 87.84 & 51 & 4.027 & .564 \\
Creativity Score & & & & .508 \\
$\quad$ Male & 86.24 & 51 & 3.625 & .543 \\
$\quad$ Female & 89.22 & 51 & 3.880 & \\
\hline
\end{tabular}


Table 4. Students' Perceived Helpfulness of Integrating Local Wisdom in Choreography Dance Course

\begin{tabular}{|c|c|c|c|}
\hline No. & Statements & $M$ & $S D$ \\
\hline 1. & $\begin{array}{l}\text { The integration of sumbang duduak (taboos in sitting) in dance makes me more } \\
\text { selective in choosing sitting movements concerning the ethics in local dancing }\end{array}$ & 4.54 & .59 \\
\hline 2. & $\begin{array}{l}\text { The integration of sumbang tagak (taboos in standing) in dance makes me more } \\
\text { selective in choosing body gestures concerning the ethics in local dancing }\end{array}$ & 4.60 & .59 \\
\hline 3. & $\begin{array}{l}\text { The integration of sumbang jalan (taboos in walking) gives me knowledge about the } \\
\text { volume of legs, head, and hand movement forming }\end{array}$ & 4.26 & .62 \\
\hline 4. & $\begin{array}{l}\text { The integration of sumbang karajo (taboos in working) gives me knowledge about } \\
\text { choosing the dance movements which are appropriate to the characters, themes, and } \\
\text { movement patterns of female and male dancers. }\end{array}$ & 4.00 & .70 \\
\hline 5. & $\begin{array}{l}\text { The integration of sumbang diam (taboos in silent) gives me rules during dancing in } \\
\text { a couple way }\end{array}$ & 4.08 & .67 \\
\hline 6. & $\begin{array}{l}\text { The integration of sumbang kato (taboos in speaking) gives me knowledge how to } \\
\text { communicate and interact with audiences }\end{array}$ & 4.00 & .59 \\
\hline 7. & $\begin{array}{l}\text { The integration of sumbang caliak (taboos in viewing) provides me knowledge of } \\
\text { eyes movement forming during dancing }\end{array}$ & 4.01 & .71 \\
\hline 8. & $\begin{array}{l}\text { The integration of sumbang tanyo (taboos in asking) provides me some rules on how } \\
\text { to ask and giving opinions in terms of creating dances in teams. }\end{array}$ & 4.00 & .67 \\
\hline 9. & $\begin{array}{l}\text { The integration of sumbang jawek (taboos in responding) provides me some } \\
\text { knowledge on how to respond and share with others in terms of creating dances. }\end{array}$ & 4.09 & .76 \\
\hline 10. & $\begin{array}{l}\text { The integration of sumbang bagaua (taboos in getting along) provides me some } \\
\text { knowledge on how to discuss and work together with teams in terms of creating } \\
\text { dances. }\end{array}$ & 4.54 & .50 \\
\hline 11. & $\begin{array}{l}\text { The integration of sumbang kurenah (taboos in acting) gives me rules on how to } \\
\text { accommodate head, hand, and leg movement forming which are appropriate to the } \\
\text { characters, themes, and movement patterns of female and male dancers. }\end{array}$ & 4.01 & .63 \\
\hline 12. & $\begin{array}{l}\text { The integration of sumbang pakaian (taboos in dressing) gives me knowledge } \\
\text { about choosing the costumes which are appropriate to the characters, themes, and } \\
\text { movement patterns of dancing. }\end{array}$ & 3.97 & .72 \\
\hline 13. & $\begin{array}{l}\text { The integration of sumbang duo baleh (the twelve taboos) increases my creative } \\
\text { thinking in terms of producing a unique movement }\end{array}$ & 4.07 & .69 \\
\hline 14. & $\begin{array}{l}\text { The integration of sumbang duo baleh (the twelve taboos) increases my creative } \\
\text { thinking in terms of producing a unique theme }\end{array}$ & 4.09 & .77 \\
\hline 15. & $\begin{array}{l}\text { The integration of sumbang duo baleh (the twelve taboos) increases my creative } \\
\text { thinking in terms of producing a unique costume }\end{array}$ & 4.02 & .70 \\
\hline
\end{tabular}

In terms of costumes, the students' perceptions were in between disagree and neutral, meaning that local wisdom did not give enough knowledge on how to choose appropriate costumes in dance performance. However, in the creativity aspect (item \#13-\#15), the students perceived that local wisdom was valuable for them in increasing their creative thinking in producing dance. All in all, local wisdom was generally helpful especially in creating movements, improving attitude, and increasing their creative thinking.

\section{Discussion}

The first research finding showed that excavating local wisdom from YouTube gives significant effect ( $p$-value $=.000$ ) to Indonesian higher students' dance performance seen from the average score of the experimental group was 84.02 and the control group was 79.30. The result conforms to the research conducted by Riyaningsih et al., (2018) that local wisdom can encourage students' intelligence. In this present research, excavating local wisdom can make the higher students realize the importance 
of learning local wisdom. They can understand the values or attitudes derived from the wisdom and they reflect the wisdom that they have learned into their dance movements so that their dance performance becomes better. The study conducted by Pedro, Stevens, \& Scheu (2018) also found that the cultural orientation involving the integration of local wisdom in teaching dance can help students to contextualize their movement. Thus, lecturers should support students with cultural awareness when they are teaching (Sööt \& Viskus, 2014), especially in teaching dance.

The study conducted by Hendriyanto, Sutopo, \& Mustofa (2019) indicated that local wisdom is integrated into life, and arts, such as dance, are also closely related to life. Local wisdom can be put as the main variable to increase students' performance in learning (Rawung, 2013; Subali, Sopyan, \& Ellianawati, 2015). This also becomes the reason why Anggraini \& Kusniarti (2015) also suggested that local wisdom should be integrated into the instructional materials. In the context of choreography dances, when students learn dance, they also learn the local wisdom that comes with it. The study conducted by Astuti (2018), who integrated the local wisdom of Sumbang Duo Baleh in her module, found the effectiveness of the local wisdom in her students' dance performance. Because Indonesia has a large number of local wisdom, and their existence is embedded and followed by people in a certain community (Humaida, Louisa, \& Lestari, 2018; Kartika, 2016; Lisdiyono, 2017), It can give meaningful contributions if further research studies will also integrate local wisdom in instructional materials to build students' moral and characters.

Furthermore, this research was not only focused on local wisdom, but the role of technology was also involved. YouTube was used as the media in which the students watched some dances and learned the local wisdom that appeared in the dances. The findings of the research showed that the excavating local wisdom from YouTube videos can increase students' dance performance. Using an internet connection, they can easily access the dancing videos that they were going to learn and can criticize several aspects related to the local wisdom that they identified from every movement of the dances.
This research findings also confirmed that videos on YouTube can bring the students to discussion activity, and it also stimulated students' critical thinking (Zboun, Ghammaz, \& Zboun, 2018). It also proved that the students in the choreography course participated in discussions about the local wisdom through the videos given. They accessed the videos on YouTube and criticized the movements of dancers in the videos. They compared with the values of local wisdom, namely sumbang duo baleh (the twelve taboos). The results of their criticizing became the foundation to improve their quality of dance performance. Moreover, the videos that were watched on YouTube became the inspirations to create their dances, and the results of criticizing the movements and forms of the dancers on the videos became the foundation to control their movements.

The use of technology as a useful and powerful media in this millennial era also gives contributions to the improvement of students' learning outcomes (Lai \& Bower, 2020). Specifically, the popularity of YouTube gives chances to lecturers to take the benefits and integrate it as the media of learning in class. The combination of YouTube and discussion activities can create positive effects on the students' learning outcomes (Fleck et al., 2014). Besides, Olasina (2017) found that YouTube can be fitted to the pedagogy. She claimed that YouTube can be used as a fundamental platform to develop techno-pedagogy in classrooms. Besides, the research which is conducted by Buzzetto-More (2015) found that YouTube can enhance students' efficacy and engagement during the learning process. Fleck et al., (2014) also claimed that YouTube is beneficial, helpful, and entertaining according to the students' perception. However, the videos which are existed on YouTube should be selected and evaluated critically to engage students' motivation in the process of learning. Students can be asked to evaluate the content of the videos from YouTube to increase their critical thinking (Olasina, 2017).

The second research finding showed that after excavating local wisdom from YouTube had implemented, female students are better than male students in terms of creativity. The finding of this research was in line with the study conducted by Matud et al., (2007) that females have higher creativity than males. In specific, 
Baer \& Kaufman (2008) who have concerned about gender differences in creativity, the scores of females are higher than males. Surprisingly, in the context of dancing, this research highlighted that females' creativity scores were higher than males. It indicates that females have higher sensitivity than males so that they can consider the values of local wisdom toward every movement that was created. As a result, the females' creativity, which consists of fluency, elaboration, quality, and originality achieved better than males.

Besides, although males are higher than females in leadership (Parmentier, Le LoarneLemaire, \& Belkhouja, 2017), in this research, using their sensitivity, females can produce dance more creative than males in terms of originality, fluency, flexibility, and elaboration. This finding supported the studies conducted by Amado et al., (2017) and Naderi et al., (2010) that females have higher positive psychological and sensitivity than males. In addition, as stated by Indrayuda (2016), the values of local wisdom can control every expression of female dancers than males. It indicated that local wisdom which had been criticized through YouTube videos can not only improve the higher students' performance in general, but it also formed and shaped the females' creativity. However, although the females' creativity was higher than males, the creativity of males was increased after giving the treatment. Riyaningsih et al., (2018) have claimed that the students in the choreography course have to push their creativity in creating their dances. They also found that students' creativity can be increased through the understanding of local wisdom, and creativity can also link to students' dance performance. It means that the awareness of local wisdom that students' have can make them explore more on what aspects they have to add to their dance movements. Excavating local wisdom values provides inspirations for students to create their own movements and improve the quality of their local dance movements.

The third research finding showed that excavating local wisdom through YouTube videos was perceived helpfulness to students' dance performance and creativity. Specifically, they can improve how they did sitting and standing movements. They also perceived helpfulness in how they collaborate with other dancers. It means that it is not only about integrating local wisdom, but the values in the local wisdom that can improve students' attitudes also affect their dance quality. Pedro et al., (2018) also said that local wisdom can build relationships with each other, trust, and support. Besides, their creativity was also increased in terms of creating movements, improving attitude, and increasing their creative thinking. The finding added to the concept which has been conceptualized by the previous research conducted by Lopez (2019), who claims that the commitment and discipline which are built through the content of local wisdom make dances produced by students better. It means that integrating local wisdom in choreography dance can not only build students' characters, commitment, and discipline, but it also increases students' performance, creativity, and collaborative skill.

Based on the discussion above, it can be concluded that culture can affect human life quality (Georgios, Ioannis, Olga, Dimitris, \& Maria, 2018), and the combination of culture and education in class increases students' performance and creativity. The excavating local wisdom from YouTube videos can also give awareness to students to appreciate the products of cultures in their communities (Sompong, Rampai, \& Kheerajitt, 2015). Besides, the research conducted by Anggraini \& Kusniarti (2015) added that local wisdom can potentially build students' characters, especially for the young generation. Riyaningsih et al., (2018) have also proved that traditional dance in which local wisdom are always existed in the whole movements can establish students' character. They said that responsibility, cooperation, and tolerance can be established through the integration of local wisdom in choreography dances. The innovations of teaching involving local wisdom as a product of culture can improve several aspects related to students' learning outcomes. It suggests further research studies to integrate certain local wisdom into both contents of learning and instructional media.

\section{CONCLUSION}

In a higher educational context, lecturers may develop students' creativity and motivate them to produce innovations. In choreography dance, the lecturers can increase students' awareness in understanding the local wisdom 
values. The local wisdom can be a bridge to link students' cultural awareness to their dance performance. Although the current situation teaching should be combined with technology, the local wisdom has to control the works of it, especially in producing local dances. This research has revealed that local wisdom values have important roles in controlling students' dance originality, quality, and form, particularly in local dances. Besides, local wisdom does not inhibit students to explore their creativity. Through the use of media, students get many sources (i.e. videos from YouTube) to inspire them to produce dances. They can stimulate their critical thinking to analyze and evaluate the elements of dance that they have watched, and then, they create their own improvement by considering the values of local wisdom.

\section{REFERENCES}

Alaways, S. (2020). Professional performance experience versus pedagogical knowledge in teaching technique class as a creative process. Journal of Dance Education, 20(4), 214-223. https://doi.org/10.1080/1 5290824.2019.1607352.

Amado, D., Sanchez-Miguel, P. A., \& Molero, P. (2017). Creativity associated with the application of a motivational intervention programme for the teaching of dance at school and its effect on the both genders. PLoS ONE, 12(3), 1-14. https://doi. org/10.1371/journal.pone.0174393.

Anggraini, P., \& Kusniarti, T. (2015). The insertion of local wisdom into instructional materials of Bahasa Indonesia for 10th grade students in senior high school. Journal of Education and Practice, 6(33), 89-92. https://www.iiste.org/Journals/ index.php/JEP/article/view/27371.

Anttila, E., Martin, R., \& Nielsen, C. S. (2019). Performing difference in/through dance: The significance of dialogical, or third spaces in creating conditions for learning and living together. Thinking Skills and Creativity, 31, 209-216. https:// doi.org/10.1016/j.tsc.2018.12.006.

Astuti, F. (2018, 19-20 October). Creative movement learning model in dancing for kindergarten teachers. Paper presented at the Seventh International Conference on anguages and Arts (ICLA 7), Universitas Negeri Padang, Indonesia. https://doi. org/10.2991/icla-18.2019.27.

Astuti, F. (2019). The essence of Siganjua Lalai values in dance movements of Minangkabau women. Harmonia: Journal of Arts Research and Education, 19(1), 37-47. https://doi.org/10.15294/ harmonia.v19i1.23622.

Baer, J., \& Kaufman, J. C. (2008). Gender differences in creativity. Journal of Creative Behavior, 42(2), 75-105. https:// doi.org/10.1002/j.2162-6057.2008. tb01289.x.

Butterworth, J. (2004). Teaching choreography in higher education: a process continuum model. Research in Dance Education, 5(1), 45-67. https://doi.org/10.1080/1464 $\underline{789042000190870 .}$.

Buzzetto-More, N. (2015). Student attitudes towards the integration of YouTube in online, hybrid, and web-assisted courses: an examination of the impact of course modality on perception. MERLOT Journal of Online Learning and Teaching, 11(1), 55-73. https://jolt.merlot.org/Vol11_No1. $\underline{\mathrm{html}}$.

Calamoneri, T., Dunagan, C., \& McCarthyBrown, N. (2020). Ethical dance pedagogy. Journal of Dance Education, 20(2), 55-64. https://doi.org/10.1080/152 90824.2019.1566607.

Chang, H. J., \& Hogans, A. (2019). Teaching communal dance forms. Journal of Dance Education, 00, 1-10. https://doi.org/10.10 80/15290824.2019.1652754.

Clements, L., \& Redding, E. (2020). Creativity in higher education contemporary dance. Journal of Dance Education, 20(2), 8898. https://doi.org/10.1080/15290824.201 9.1572155 .

DeWitt, D., Alias, N., Siraj, S., Yaakub, M. Y., Ayob, J., \& Ishak, R. (2013). The potential of YouTube for teaching and 
learning in the performing arts. Procedia - Social and Behavioral Sciences, 103, 1118-1126. https://doi.org/10.1016/j. sbspro.2013.10.439.

Edwards, S. D. (2018). A wisdom way of being to transform the heart of humanity. IFACPapers OnLine, 51(30), 739-743. https:// doi.org/10.1016/j.ifacol.2018.11.204.

Fleck, B. K. B., Beckman, L. M., Sterns, J. L., \& Hussey, H. D. (2014). YouTube in the classroom: Helpful tips and student perceptions. Journal of Effective Teaching, 14(3), 21-37. https://www.learntechlib. org $/ \mathrm{p} / 161216 /$.

Georgios, L., Ioannis, G., Olga, T., Dimitris, C., \& Maria, K. (2018). The effect of a traditional dance program on healthrelated quality of life as perceived by primary school students. Journal of Education and Training Studies, 6(1), 96-103. https://doi.org/10.11114/jets. v6i1.2878.

Gratsiouni, D., Koutsouba, M., Venetsanou, F., \& Tyrovola, V., (2016). Learning and digital environment of dance: The case of Greek traditional dance in Youtube. European Journal of Open, Distance and e-Learning, 19(2), 98-113. https://doi. org/10.1515/eurodl-2016-0009.

Hendriyanto, A., Suopo, B., \& Mustofa, A. (2019). The preservation strategy of Kethek Ogleng Pacitan in millennial era. International Journal of Engineering and Advanced Technology (IJEAT), 8(5C), 539-543. https://doi.org/10.35940/ijeat. E1078.0585C19.

Humaida, N., Louisa, V. M., \& Lestari, N. C. (2018). Characteristics of the local wisdom from South Borneo in ecological aspect. ESE International Journal (Environmental Science and Engineering), 1(2), 30-34. http://journal.greenvisioneers.or.id/index. $\mathrm{php} / \mathrm{ESE} /$ article/view/52.

Humphreys, K., \& Kimbrell, S. (2013). Best instructional practices for developing student Choreographers. Journal of Dance Education, 13(3), 84-91. https://doi.org/1

\subsection{0/15290824.2013.812790.}

Indrayuda, I. (2016). The existence of local wisdom value through Minangkabau dance creation pepresentation in present time. Harmonia: Journal of Arts Research and Education, 16(2), 143-152. https:// doi.rg/10.15294/harmonia.v16i2.6146.

Jackman, W. M. (2019). YouTube usage in the university classroom: An argument for its pedagogical benefits. International Journal of Emerging Technologies in Learning, 14(9), 157-166. https://doi. org/10.3991/ijet.v14i09.10475.

Kartika, T. (2016). Verbal communication culture and local wisdom: The value civilization of Indonesia nation. Lingua Cultura, 10(2), 89-93. https://doi.org/10.21512/ lc.v10i2.1424.

Lai, J. W. M., \& Bower, M. (2020). Evaluation of technology use in education: Findings from a critical analysis of systematic literature reviews. Journal of Assisted Learning, 36(3), 241-259. https://doi. org/10.1111/jcal.12412.

Lepczyk, B., Wagner, T., \& Cennamo, K. (2018). Choreography as design: A case study of a transdisciplinary university course. Journal of Dance Education, 18(4), 143153. https://doi.org/10.1080/15290824.20 $\underline{17.1377344 .}$.

Lisdiyono, E. (2017). Exploring the strength of local wisdom in efforts to ensure the environmental sustainability. International Journal of Civil Engineering and Technology (IJCIET), 8(11), 340-347. http://www.iaeme.com/MasterAdmin/ Journal uploads/IJCIET/VOLUME 8 ISSUE 11/IJCIET 08 11 036.pdf.

Lopez, B. (2019). Dance students at a two year college: Making sense of their academic, cultural, and social world. Research in Dance Education, 20(2), 174-183. https:// doi.org/10.1080/14647893.2019.159135 $\underline{8}$.

MacBean, A. (2004). Site-specific dance: Promoting social awareness in 
choreography. Journal of Dance Education, 4(3), 97-99. https://doi.org/10 $.1080 / 15290824.2004 .10387265$.

Matud, M. P., Rodriguez, C., \& Grande, J. (2007). Gender differences in creative thinking. Personality and Individual Differences, 43(5), 1137-1147. https:// doi.org/10.1016/j.paid.2007.03.006.

McClam, N, Y. (2018). Choreography: A basic approach using improvisation, 4th edition. Journal of Dance Education, 18, 140142. https://doi.org/10.1080/15290824.20 $\underline{18.1442962 .}$.

Milling, S., \& Green, S. K. (2014). Progress and process in a choreography class: Addressing formative and summative assessment issues. Journal of Dance Education, 14(4), 146-151. https://doi.org/10.1080/15290824.2014.8 73127.

Milyartini, R \& Haerani, R. (2013). Studi kasus pembelajaran tari untuk meningkatkan kreativitas dan kemampuan sosial siswa autis. [A case study on teaching dances to improve the creativity and social competence of students with autistic syndrome disorder]. Cakrawala Pendidikan, 32(3), 450-460. https://doi. org/10.21831/cp.v3i3.1632.

Musil,P, S.(2005). Examining sexual exploitation in secondary schools: Correlating student choreography and teacher efforts. Journal of Dance Education, 5(2), 43-50. https:// doi.org/10.1080/15290824.2005.103872 84.

Naderi, H., Abdullah, R., Aizan, H., T., Sharir, J., \& Kumar, V. (2010). Relationship between creativity and academic achievement: A study of gender differences. Journal of American Science, 6(1), 181-190.https:// doi.org/10.7537/marsjas060110.24.

Ohlberg, J. (2020). Choreography as "Seeing". Journal of Dance Education, 20(2), 99104. https://doi.org/10.1080/15290824.20 $\underline{19.1642478}$

Olasina, G. (2017). An evaluation of educational values of YouTube videos for academic writing. The African Journal of Information Systems, 9(4), 232-261. https://digitalcommons.kennesaw.edu/ ajis/vol9/iss $4 / 2 /$.

Parmentier, G., Le Loarne-Lemaire, S., \& Bekhouja, M. (2017). Female creativity in organizations: What is the impact of team composition in terms of gender during ideation processes? Management International, 22(1), 33-43. https://doi. org/10.7202/1053686ar.

Pedro, R., Stevens, K., \& Scheu, C. (2018). Creating a cultural dance community of practice: Building authentic Latin American dance experiences. Research In Dance Education, 19(3), 199-215. https:// doi.org/10.1080/14647893.2018.147647 $\underline{9}$.

Priyanto, W. P. (2005). Pembelajaran tari kreasi baru di Padepokan Seni Bagong Kussudiardja Yogyakarta. [Teaching newly-created dance at Padepokan Seni Bagong Kussudiardja]. Cakrawala Pendidikan, 24(2), 307-328. https://doi. org/10.21831/cp.v0i2.373.

Rawung, I. Y. (2013). Preserving local wisdom through teaching and learning activity at SDN Ranononcu. Jurnal Kependidikan. 6(1), 10-31. https://ojs.unsimar. ac.id/index.php/kependidikan/article/ download/62/59.

Riyaningsih, E., Maryono, M., \& Harini, H. (2018). Establishment of learners' character through learning traditional dance in senior high school. Harmonia: Journal of Arts Research and Education, 18(1), 13-27. https://doi.org/10.15294/ harmonia.v18i1.12575.

Sompong, N., Rampai, N., \& Kheerajitt, C. (2015). Knowledge management of local wisdom model for tourism along the route of lower central provinces of Thailand. Turkish Online Journal of Educational Technology, (August), 271-276. https:// kukr.lib.ku.ac.th/db/kukr/search_detail// result/339240. 
Sööt, A., \& Viskus, E. (2014). Contemporary approaches to dance pedagogy-The challenges of the $21^{\text {st }}$ century. Procedia - Social and Behavioral Sciences, 112, 290-299. https://doi.org/10.1016/j. sbspro.2014.01.1167.

Subali, B., Sopyan, A., \& Ellianawati, E. (2015). Developing local wisdom based science learning design to establish positive character in elementary school. Jurnal Pendidikan Fisika Indonesia, 11(1), 1-7. https://doi.org/10.15294/jpfi.v11i1.3998.

Triana, D. D. (2015). The ability of choreography creative thinking. Harmonia: Journal of Arts Research and Education, 15(2), 119125. https://doi.org/10.15294/harmonia. v15i2.4555.

Urmston, E., \& Aujla, I. J. (2019). Values, attributes, and practices of dance artists in inclusive dance talent development contexts. Journal of Dance Education, 00, 1-10. https://doi.org/10.1080/15290824.2 019.1652755 .

Van Dyke, J. (2005). Teaching choreography: Starting with craft. Journal of Dance Education, 5(4), 116-124. https://doi.org $\not 10.1080 / 15290824.2005 .10387300$.

Wicaksono, H. Y. (2009). Kreativitas dalam pembelajaran music. [Creativity in learning music]. Cakrawala Pendidikan, 28(1), 1-12. https://doi.org/10.21831/ cp.v1i1.42.

Wilmot, L. R. L. (2019). The role of teaching artists in postsecondary education. Journal of Dance Education, 00, 1-10. https://doi.org/10.1080/15290824.2019.1 $\underline{652756}$.

Wu, H.-Y., Wu, H.-S., Chen, I.-S., \& Chen, H.-C. (2014). Exploring the critical influential factors of creativity for college students: A multiple criteria decision-making approach. Thinking Skills and Creativity, 11, 1-21. https://doi.org/10.1016/j. tsc.2013.09.004.

Zboun, M. S. A., Ghammaz, S. A. D. A., \& Zboun, M. S. A. (2018). The impact of the use of youtube and facebook on students' academic achievement in geography course at the university of jordan for the bachelor's degree. Modern Applied Science, 12(3), 164-174. https://doi. org/10.5539/mas.v12n3p164. 